\title{
Herd Level Antimicrobial Resistance in Beef Calves in Switzerland 1986 through 2011
}

\author{
Michael Hässig1 ${ }^{*}$, Sarina Eugster1, Frazer Iain Lewis ${ }^{2}$ \\ ${ }^{1}$ Department of Farm Animals, Section for Ambulatory Field Clinic and Herd Health, Zurich, Switzerland \\ ${ }^{2}$ Section for Epidemiology, University of Zurich, Zurich, Switzerland \\ Email: *mhaessig@vetclinics.uzh.ch
}

Received 9 September 2014; revised 15 October 2014; accepted 3 November 2014

Copyright (C) 2014 by authors and Scientific Research Publishing Inc.

This work is licensed under the Creative Commons Attribution International License (CC BY). http://creativecommons.org/licenses/by/4.0/

(c) $\underset{\mathrm{EY}}{\mathrm{B}}$ Open Access

\section{Abstract}

The increasing emergence of antimicrobial resistance in food animals is a growing global concern and is closely linked to animal husbandry practices. In this study we describe the changement of antimicrobial resistance in beef calf production in Switzerland from 1986 through 2011. Data were collected from farms with known calf herd problems, such as diarrhoea or pneumonia, along with antimicrobial resistance from those herds. The Herd Health Section of the University of Zurich visited each farm. Samples were analysed for bacterial growth and resistance test commonly indicated in diseases such as calf pneumonia and diarrhoea. Each resistance test comprised of samples from at least three diseased animals. For diarrhoea, a faeces sample was used, for pneumonia a deep nasal swab was taken. In nasal swabs, only batches yielding considerable bacterial growth in three individual animal samples were included for diagnosis. Other growth of bacteria was considered as contamination. The results consisted of bacterial resistance to antibiotics against defined diseases such as calf diarrhoea and calf pneumonia at herd level. This approach is reflecting the situation as found in practice when a calf has to be treated without delay and without results from further laboratory diagnostics. In diarrhoea cases, four antibiotics showed no bacterial resistance. Bacterial resistance of below $10 \%$ was observed to three antibiotics. Up to $\mathbf{2 0 \%}$ bacterial resistance was found to two antibiotics. Eighty per cent and over was found to be six antibiotics. Bacterial resistance to two antibiotics was found in over $90 \%$ of samples and all samples were resistant to one antibiotic. In pneumonia three antibiotics showed no resistance; one was below $10 \%$; four antibiotics were below $20 \%$. Over $80 \%$ of samples were resistant to four antibiotics. One resistance was over $\mathbf{9 0 \%}$ and all bacterial samples were resistant to two antibiotics. Differences in bacterial resistance between pneumonia and diarrhoea in two study periods with equal cases, i.e. 1986-2006 and 2007-2011 were found. A reduction in bacterial resistance can be found in 5 out of 7 cases, when the amount of the respective antibiotic was reduced over time. This finding raises the obvious question whether antibiotics should be removed from the marked ones by a period of about 10 years. This would help to control not only bacterial resistance but also the

"Corresponding author.

How to cite this paper: Hässig, M., Eugster, S. and Lewis, F.I. (2014) Herd Level Antimicrobial Resistance in Beef Calves in Switzerland 1986 through 2011. Open Journal of Veterinary Medicine, 4, 247-254.

http://dx.doi.org/10.4236/ojvm.2014.411029 
use of the limited amount of antimicrobial drugs available. Such a control program would need to be established by international and national drug agencies as well as the pharmaceutical industry. Such a program would require extensive international validation.

\author{
Keywords
}

\title{
Bovine, Calf, Pneumonia, Diarrhoea, Resistance Test
}

\section{Introduction}

The increasing emergence of antimicrobial resistance in food animals is a growing global concern and is closely linked to animal husbandry practices. We present here a prevalence study of antimicrobial resistance in beef calf production in Switzerland. Typical husbandry practice in Switzerland is for beef calves to leave their farm of origin around the $10^{\text {th }}$ day post partum only protected by a passive immunity, i.e. by the immunity acquired by the colostrum transfer [1]. This early transport of calves is the result of a high demand for white or light reddish beef by the consumer, resulting in the slaughter of beef calves at an age of approximately four months. To get an acceptable margin of price by daily weight gain, calves must enter the beef calf farm at this early age. The presence of calves which have exhibited an IgG transfer failure, and therefore have no protection, is commonplace [2]. Moreover, protection provided by colostral antibodies is only present for the infectious agents in the farm of origin, and not in the new stable where the young beef calves are sent, often in groups of 50 and more, each originating from a different dairy farm. Both these factors are classical risk factors for diseases, which thrive on crowded conditions. To overcome such disease exposure issues, antibiotic therapy is widely utilized in beef calf production. In Switzerland close to $100 \%$ of calves are treated with antibiotics. Antibiotic treatment is often used as protective treatment by mixing antibiotics into the milk served by an automatic feeding system or as topdressing on bucket milk. The veterinary practitioner chooses the antibiotic by clinical rather than by aetiological diagnosis. This is followed by information on availability by law, commercial availability and information of bacterial resistance in time and location. No antimicrobial resistance test is normally performed. If the initial treatment does not meet the necessary goals, then a second, and then a third choice therapy is tried.

We present here a study of the prevalence of antimicrobial resistance relevant to the major diseases in beef calf production, i.e. pneumonia and diarrhoea, exploring this over two study periods with equal cases, i.e. 19862006 and 2007-2011. Identifying emerging trends in the magnitude and speed of change in bacterial resistance profiles is an essential first step in identifying potentially poor animal husbandry practices, with regard to the use of antimicrobial therapies.

\section{Animals, Material and Methods}

The study protocol had not to be approved by the Animal Care Committee of the Canton of Zurich, Switzerland, because all samples were taken during standard veterinary diagnostically work.

A total of 1847 dairy farms were visited. Out of these 1847 farms, 49 (2.7\%) had herd problems with calves, mainly diarrhoea or pneumonia. A herd problem was defined according to Radostits and Blood [3] where at least $10 \%$ of the animals at risk have to show a certain disease (Figure 1). The farm size consisted of 10 to 100 meat calves. All farms were visited at least once and samples were taken once during the first visit. All sample were transferred to the laboratory within one day. Standard microbiological analysis for bacteria was performed and a resistance test was followed. Between 1986 and 2011 different resistance tests were performed, typically utilizing disk-diffusion and cluster analysis of inhibition-zone patterns.

As for herd problems the case definition is set at one farm. In 26 cases (53\%) the diseased calves were less than or equal to one month of age. All calves under investigation were less than six months old. Samples were analysed for bacterial resistance against specific antibiotics, but results were collected, for bacterial resistance against antimicrobials commonly indicated in diseases such as calf diarrhoea and calf pneumonia at a herd level. Bacteriological findings were checked to be a possible causative agent and in accordance with the herd problem for calf pneumonia or diarrhoea according to Radostits and Blood [3]. A resistance test comprised of samples from between three to eight diseased animals. For diarrhoea a faeces sample was used, for pneumonia a deep nasal swab was taken. In nasal swabs only medium (++) or intensive (+++) growth in all 3 samples was used for 
diagnosis. Other growth of bacteria was considered as contamination.

On these 49 farms with calf problems as a herd problem, 290 samples for bacteriological testing were collected. The isolates are given in Table 1.

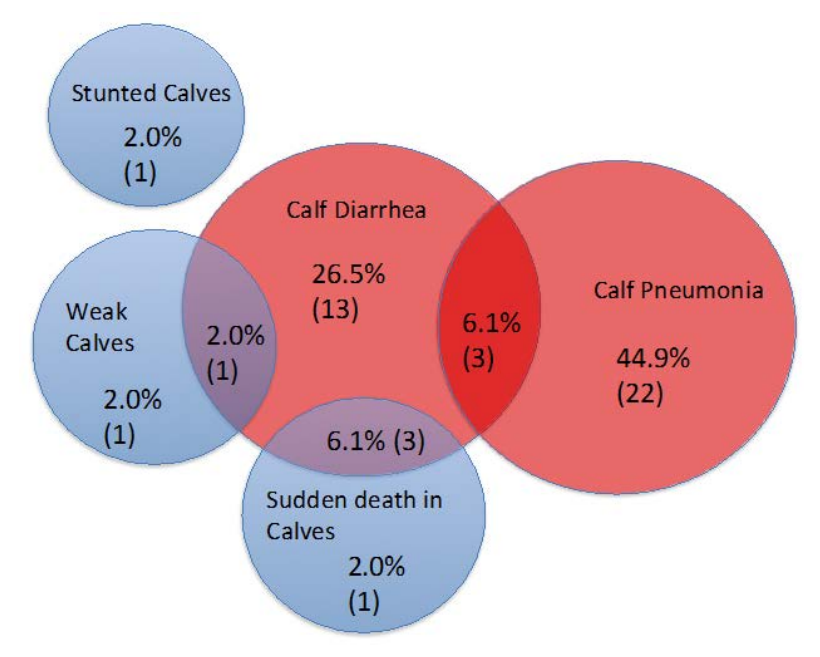

Figure 1. Clinical signs in meat calf farms in Switzerland between 1986 and 2011.

Table 1. Not cumulative frequency of bacterial isolates of samples from between three to eight diseased calves in herds with problems. For diarrhoea a faeces sample was used, for pneumonia a deep nasal swab was taken. In nasal swabs only ++ or +++ identical growth in all samples was used for diagnosis.

\begin{tabular}{|c|c|c|}
\hline Bacteria & $\mathrm{N}$ & $(\%)$ \\
\hline E. coli & 87 & 30 \\
\hline Staphylococcus spp. & 43 & 15 \\
\hline Streptococcus spp. & 30 & 10 \\
\hline Salmonella spp. & 30 & 10 \\
\hline Pasteurella spp. & 25 & 9 \\
\hline Clostridia spp. & 20 & 7 \\
\hline Proteus spp. & 19 & 7 \\
\hline Mycoplasma spp. & 14 & 5 \\
\hline Enterococcus spp. & 8 & 3 \\
\hline Arcanobacterium spp. & 3 & 1 \\
\hline Bacillius spp. & 3 & 1 \\
\hline Bordetella & 3 & 1 \\
\hline Klebsiella spp. & 3 & 1 \\
\hline Fusobacterium spp. & 2 & 1 \\
\hline Shigella spp. & 2 & 1 \\
\hline Actinomyces spp. & 2 & 1 \\
\hline Aeromonas spp. & 2 & 1 \\
\hline Chlamydia spp. & 1 & $<1$ \\
\hline Corynebacterium spp. & 1 & $<1$ \\
\hline Total & 290 & $(100)$ \\
\hline
\end{tabular}


A comparison of bacterial resistance rates for various antibiotics between farms with calf pneumonia and calf diarrhoea, as a herd problem, was made. All tests were performed either at the institute for Food Security or at the institute for Veterinary Bacteriology according to accredited procedures. The laboratory procedure varied over time slightly but in general the procedure was as followed: Bacteri alanalyses were performed using different agarplates (Oxoid, Columbia Sheep BloodAgar, Hampshire, UK; Oxoid, MacConkey, Hampshire, UK) and incubated for 48 hours at $37^{\circ} \mathrm{C}$ under aerobicconditions. After incubation, the different bacteria were isolated and purified by restreaking on agarplates. A variety of selective media were used in case of suspicion of a respective bacteriological organism. The total aerobic bacterial grow was determined on Colombia blood agar plates $^{\odot}$ and coliforms on Gassner agar plates ${ }^{\odot}$. Enterococcal colonies were grown on bile esculinazide agar plates $^{\odot}$ and staphylococcal and streptococcal colonies on Colombia CNA agar plates ${ }^{\odot}$. Plates were incubated aerobically for 24 hours at $37^{\circ} \mathrm{C}$. De Man Rogosa Sharpe agar ${ }^{\odot}$ was used to grow lactobacilli under aerobic conditions for 72 hours at $30^{\circ} \mathrm{C}$. Clostridial colonies were cultured on lactose egg yolk agar plates after strict anaerobic incubation at $37^{\circ} \mathrm{C}$. The susceptibility of the isolates was evaluated according to the European Committee on Antimicrobial Susceptibility Testing (EUCAST). A total of 76 bacteriological resistance tests out of 49 farms were evaluated.

Years 1986 through 2006 were compared with years 2007 through 2011. These unequal sampling periods were used to get on one hand equal sample size and on the other hand the use of antibiotics was newly regulated by federal law: The use of antibiotics in meat calves was only allowed by an official receipt with exact calculation of the amount of used antibiotics and periodically control of the feeding system. Single year calculations were not performed due to the small amount of cases.

All dairy farms were assigned to one of ten geographical regions according to their respective Swiss zip code.

Results of bacterial resistance were compared with the amount of antibiotics used in farm animals in Switzerland (Data provided by Swiss medic, Arch-vet 2007 until 2011).

The data were analysed using Stata (Stata Corp., 2011; Stata Statistical Software: Release 12.0; College Station, Texas, USA). Frequency counts, means and standard deviations were calculated. For n (expected) $\geq 5$ in each cell a Chi-Square-test was performed. For n (expected) $\leq 5$ then a Fisher's exact test was instead used. A p-value of $\leq 0.05$ was considered as significant. A p-value between 0.05 and 0.2 was considered as a tendency.

\section{Results}

Out of 49 beef calf farms with herd problems, 22 (44.9\%) had problems with pneumonia, 13 (26.5\%) had diarrhoea, three (6.1\%) had pneumonia and diarrhoea. The distribution of main herd problems is presented in Figure 1.

The spatial distribution revealed that most of the farms sampled came from the region of Zurich (20, 40.8\%) followed by the central part (6,18.4\%), eastern and the northeastern part of Switzerland (each 5, 10.2\%). This distribution is indicative of convenience sampling due to local accessibility of the eastern part of Switzerland to the University of Zurich. No spatial differences were found.

In all cases, i.e. calf diarrhoea and pneumonia, Florfenicol was the only individual antibiotic which showed no bacterial resistance over the whole study period. A prevalence for antimicrobial resistance of up to $10 \%$ within the 49 meat calf farms was observed to Marbofloxacin and Amikacin, between 10\% - 20\% to Apramycin and Ceftiofur and below 30\% Amoxicillin/Clavulanicacid, Cefquinom, Enrofloxacin and Gentamicin. Over 70\% of cases i.e. meat calf farms with either calf pneumonia or diarrhoea were found to be resistant to Fusidic acid, Spiramycin and Sulfamethoxazole. Erythromycin, Clindamycin, Lincomycin and Tylosin showed more than $80 \%$ bacterial resistance. Bacterial resistance to Metronidazole was observed in $92.5 \%$ of cases.

In diarrhoea cases Apramycin, Florfenicol, Marbofloxacin and Ceftiofur showed no bacterial resistance. Bacterial resistance of below 10\% was observed to Enrofloxacin, Gentamicin and Spectinomycine. Up to 20\% bacterial resistance was found to Amikacin and Cotrimoxazole. Eighty per cent and over was found to Pristinamycine, Penicillin G, Lincomycin, Erythromycin, Fusidinacid and Clindamycin. Bacterial resistance to Spiramycin and Tylosin was found in over $90 \%$ of samples and all samples were resistant to Metronidazole.

In pneumonia Ceftiofur, Florfenicol and Marbofloxacin showed no bacterial resistance. Apramycin was below 10\%. Amikacin, Cefquinom, Enrofloxacin and Gentamicin were below 20\%. Over 80\% of samples were resistant to Clindamycin, Erythromycin, Lincomycin and Sulfamethoxazole. Bacterial resistance for Tylosin was over $90 \%$ and all samples were resistant to Metronidazole and Spiramycin.

Differences in bacterial resistance over the whole study period between pneumonia and diarrhoea are pre- 
sented in Table 2. A difference over time by the amount of used antibiotics was significant for Enrofloxacine (p $<0.01$, Pearson chi ${ }^{2}$-test) exact and a tendency was found for Doxycycline ( $\mathrm{p}=0.13$, Pearson chi $^{2}$-test), Gen-

Table 2. Differences of antimicrobial resistance in calf pneumonia and diarrhoea in herds with known health problems between 1986 and 2011.

\begin{tabular}{|c|c|c|c|c|}
\hline Antibiotic & $\begin{array}{l}\text { Resistance in diarrhoea } \\
\text { (\%) }\end{array}$ & $\begin{array}{l}\text { Resistance/tested in } \\
\text { diarrhoea }(\mathrm{n} / \mathrm{N})\end{array}$ & $\begin{array}{l}\text { Resistance in pneumonia } \\
\text { (\%) }\end{array}$ & $\begin{array}{l}\text { Resistance/tested in } \\
\text { pneumonia }(\mathrm{n} / \mathrm{N})\end{array}$ \\
\hline Amikacin & 11.1 & $1 / 9$ & 11.1 & $1 / 9$ \\
\hline Amox./Clavulanic. & 33.3 & $6 / 18$ & 22.2 & $6 / 27$ \\
\hline Amoxicillin & 69.0 & $20 / 29$ & 59.5 & $22 / 37$ \\
\hline Ampicillin & 75.0 & $15 / 20$ & 68.2 & $15 / 22$ \\
\hline Apramycin & 0.0 & $0 / 14$ & 9.5 & $2 / 21$ \\
\hline Cefalotin & 73.3 & $11 / 15$ & 57.1 & $12 / 21$ \\
\hline Cefoperazone & 33.3 & $5 / 15$ & 33.3 & $7 / 21$ \\
\hline Ceftiofur & 0.0 & $0 / 3$ & 0.0 & $0 / 3$ \\
\hline Cefquinom & 37.5 & $3 / 8$ & 15.4 & $2 / 13$ \\
\hline Chloramphenicol & 39.3 & $11 / 28$ & 36.3 & $12 / 33$ \\
\hline Clindamycin & 89.5 & $17 / 19$ & 88.9 & $16 / 18$ \\
\hline Colistine & 31.8 & $7 / 22$ & 41.4 & $12 / 29$ \\
\hline Cotrimoxazole & 13.3 & $2 / 15$ & 23.8 & $5 / 21$ \\
\hline Doxycycline & 51.7 & $15 / 29$ & 48.7 & $18 / 37$ \\
\hline Enrofloxacin & 3.5 & $1 / 29$ & 18.9 & $7 / 37$ \\
\hline Erythromycin & 85.7 & $24 / 28$ & 84.9 & 28/33 \\
\hline Flumequin & 33.3 & $5 / 15$ & 57.1 & $12 / 21$ \\
\hline Florfenicol & 0.0 & $0 / 6$ & 0.0 & $0 / 6$ \\
\hline Fusidic acid & 86.7 & $13 / 15$ & 71.4 & $15 / 21$ \\
\hline Gentamicin & 6.9 & $2 / 29$ & 10.8 & $4 / 37$ \\
\hline Kanamycin & 33.3 & $5 / 15$ & 33.3 & $7 / 21$ \\
\hline Lincomycin & 86.7 & $13 / 15$ & 85.7 & $18 / 21$ \\
\hline Marbofloxacin & 0.0 & $0 / 9$ & 0.0 & $0 / 12$ \\
\hline Metronidazole & 100.0 & $15 / 15$ & 100.0 & $21 / 21$ \\
\hline Neomycin & 58.3 & $7 / 12$ & 72.7 & $8 / 11$ \\
\hline Nitrofurantoin & 32.1 & $9 / 28$ & 30.3 & $10 / 33$ \\
\hline Oxolinsäure & 59.1 & $13 / 22$ & 71.4 & $20 / 28$ \\
\hline Penicillin G & 89.7 & $26 / 29$ & 75.7 & $28 / 37$ \\
\hline Pristinamycin & 80.0 & $12 / 15$ & 61.9 & $13 / 21$ \\
\hline Polymyxine & 42.9 & $3 / 7$ & 42.9 & $3 / 7$ \\
\hline Rifampicin & 66.7 & $10 / 15$ & 52.4 & $11 / 21$ \\
\hline SA/Trimet. & 26.7 & $4 / 15$ & 29.4 & $5 / 17$ \\
\hline Spectinomycine & 6.7 & $1 / 15$ & 23.8 & $5 / 21$ \\
\hline Streptomycin & 55.2 & $16 / 29$ & 56.8 & $21 / 37$ \\
\hline Spiramycin & 91.7 & $11 / 12$ & 100.0 & $11 / 11$ \\
\hline Sulfamethoxazole & 72.4 & $21 / 29$ & 81.1 & $30 / 37$ \\
\hline Tetracycline & 46.7 & $7 / 15$ & 47.6 & $10 / 21$ \\
\hline Tylosin & 93.3 & $14 / 15$ & 90.5 & $19 / 21$ \\
\hline
\end{tabular}

$\mathrm{n} / \mathrm{N}=$ antimicrobial resistant samples in meat calf farms with a herd problem/total antimicrobial samples in meat calf farms with a herd problem. 
tamycin $(\mathrm{p}=0.08$, Fisher’s exact-test), Notrofurantoin $(\mathrm{p}=0.11$, Fisher’s exact-test $)$ and Oxolinacid $(\mathrm{p}=0.13$, Fisher's exact-test).

In Table 3 differences over time for pneumonia and diarrhoea are presented. Years 1990 through 2006 were

Table 3. Prevalence of antimicrobial resistance between 1986-2006 and 2007-2011.

\begin{tabular}{|c|c|c|c|c|}
\hline Antibiotic & $\begin{array}{c}\text { Resistance 1986-2006 } \\
\text { (\%) }\end{array}$ & $\begin{array}{c}\text { Resistant/tested } \\
1986-2006(\mathrm{n} / \mathrm{N})\end{array}$ & $\begin{array}{c}\text { Resistance 2007-2011 } \\
\text { (\%) }\end{array}$ & $\begin{array}{l}\text { Resistant/tested 2007-2011 } \\
(\mathrm{n} / \mathrm{N})\end{array}$ \\
\hline Amikacin & 33.3 & $1 / 3$ & 0.0 & $0 / 7$ \\
\hline Amox./Clavulanic. & 14.3 & $1 / 7$ & 25.0 & $13 / 52$ \\
\hline Amoxicillin & 56.0 & $14 / 25$ & 45.3 & $24 / 53$ \\
\hline Ampicillin & 58.3 & $14 / 24$ & 62.5 & $5 / 8$ \\
\hline Apramycin & & $0 / 0$ & 15.4 & $8 / 52$ \\
\hline Cefalotin & 50.0 & $1 / 2$ & 53.8 & $28 / 52$ \\
\hline Cefoperazon & 50.0 & $1 / 2$ & 40.4 & $21 / 52$ \\
\hline Ceftiofur & 0.0 & $0 / 1$ & 25.0 & $1 / 4$ \\
\hline Cefquinom & 50.0 & $1 / 2$ & 26.8 & $11 / 41$ \\
\hline Chloramphenicol & 38.1 & $8 / 21$ & 43.4 & $23 / 53$ \\
\hline Clindamycin & 90.0 & $18 / 20$ & 87.5 & $7 / 8$ \\
\hline Colistine & 33.3 & $4 / 12$ & 42.3 & $22 / 52$ \\
\hline Cotrimoxazole & 100.0 & $1 / 1$ & 42.3 & $22 / 52$ \\
\hline Doxycycline & 60.0 & $15 / 25$ & 41.5 & $22 / 53$ \\
\hline Enrofloxacin & 0.0 & $0 / 25$ & 32.1 & $17 / 53$ \\
\hline Erythromycin & 76.2 & $16 / 21$ & 83.0 & $44 / 53$ \\
\hline Flumequine & 0.0 & $0 / 1$ & 44.2 & $23 / 52$ \\
\hline Florfenicole & & 0 & 0.0 & $0 / 7$ \\
\hline Fusidic acid & 100.0 & $1 / 1$ & 73.1 & $38 / 52$ \\
\hline Gentamicin & 8.0 & $2 / 25$ & 26.4 & $14 / 53$ \\
\hline Kanamycin & 100.0 & $1 / 1$ & 42.3 & $22 / 52$ \\
\hline Lincomycin & 100.0 & $1 / 1$ & 82.7 & $43 / 52$ \\
\hline Marbofloxacin & 0.0 & $0 / 6$ & 14.3 & $1 / 7$ \\
\hline Metronidazole & 100.0 & $1 / 1$ & 92.3 & $48 / 52$ \\
\hline Neomycin & 66.7 & $12 / 18$ & 50.0 & $1 / 2$ \\
\hline Nitrofurantoin & 19.0 & $4 / 21$ & 39.6 & $21 / 53$ \\
\hline Oxolinacid & 78.6 & $11 / 14$ & 53.8 & $28 / 52$ \\
\hline Penicillin G & 68.0 & $17 / 25$ & 67.9 & $36 / 53$ \\
\hline Pristinamycine & 100.0 & $1 / 1$ & 59.6 & $31 / 52$ \\
\hline Polymyxine & 33.3 & $3 / 9$ & 0.0 & $0 / 1$ \\
\hline Rifampicin & 100.0 & $1 / 1$ & 36.5 & $19 / 52$ \\
\hline SA/Trimet. & 37.5 & $9 / 24$ & 0.0 & $0 / 2$ \\
\hline Spectinomycine & 0.0 & $0 / 1$ & 32.7 & $17 / 52$ \\
\hline Streptomycin & 72.0 & $18 / 25$ & 56.6 & $30 / 53$ \\
\hline Spiramycin & 77.8 & $14 / 18$ & 100.0 & $2 / 2$ \\
\hline Sulfamethoxazole & 76.0 & $19 / 25$ & 79.2 & $42 / 53$ \\
\hline Tetracycline & 100.0 & $1 / 1$ & 51.9 & $27 / 52$ \\
\hline Tylosin & 100.0 & $1 / 1$ & 86.5 & $45 / 52$ \\
\hline
\end{tabular}

$\mathrm{n} / \mathrm{N}=$ antimicrobial resistant samples in meat calf farms with a herd problem/total antimicrobial samples in meat calf farms with a herd problem. 
compared with years 2007 through 2011. These unequal sampling periods were used to get equal sample size. Single year calculations were not performed due to the small amount of cases.

\section{Discussion}

Our analysis reveals a number of valuable new insights into clinical procedures in practice in relation to the spread and emergence of antimicrobial resistance in beef calf production. On the one hand bacteriological resistance was not measured as resistance to a certain bacteria against a given antibiotic, but rather resistance against a specific disease, i.e. calve pneumonia and diarrhoea. This approach is in accordance with the situation of a practitioner who is treating a disease without any laboratory information at first hand rather than the causative bacteria. The bacterial resistance, which led to a bacterial resistance against a certain disease, was measured at a herd level by combining at least three deep nasal swabs. Only considerable bacterial growth $(++$ to +++$)$ was considered as important. Minor growth $(+)$ and mixed flora were not considered as important.

Even calf pneumonia and diarrhoea is a major herd health problem in Switzerland only 49 cases, representing $2 \%$ of all herd problems, were referred to the herd health unit of the University of Zurich. This is due to the very small margin of financial gain in meat calf production, which leads to the "try and error" method in selecting drugs and not to use any expensive laboratory diagnostics [11].

Only Enrofloxacin (Baytril ${ }^{\circledR}$ ) showed a substantial difference in bacterial resistance between calf pneumonia and diarrhoea. This might be the result of its frequent use in calf pneumonia because it is normally sensitive to the most frequent infectious bacteria in calf pneumonia [4].

Due to the long study period, i.e. 1986 to 2011, some antibiotics were newly introduced to the antibiogram and some were skipped. The percentages have to be used with caution due to the low number of tests performed.

Out of the 38 antibiotics tested, only Enrofloxacin (Baytril ${ }^{\circledR}$ ) showed a substantial increase in bacterial resistance between our first time block 1986 and 2006, and our second time block between 2007 and 2011. Enrofloxacin (Baytril ${ }^{\circledR}$ ) is actually used very frequent in veterinary medicine [5]. The Swiss federal agency for drug release (Swiss medic) reported for 2011 a rise in the use of Fluoroquinolones. Enrofloxacin is part of the Fluoroquinolones [5]. This is important because Quinolones are considered as reserve antibiotics in human and veterinary medicine.

ARCH-vet found for 2010 a high prevalence of bacterial resistance against Sulfamethoxazole, Streptomycin, Tetracycline, Erythromycin and Ampicillin [5]. Cephalosporins of the third and fourth generation were sold more and more between 2006 and 2010 [5]. An increase in bacterial resistance rates to these drugs in food animals has therefore to be very carefully considered as these groups of antibiotics belong to the most important group in veterinary as well as human medicine. If our results of different bacterial resistance over time are compared with the amount of antibiotics used in farm animals in Switzerland (Data provided by Swiss medic, Arch-vet 2007 until 2011), a reduction in bacterial resistance can be found in 5 out of 7 cases when the total amount of a certain used antibiotic was decreased. In 3 out of 3 cases the bacterial resistance kept steady when the amount of antibiotic used was increased.

The overall situation of antimicrobial resistance within the Swiss farm animal population is stable [4]. A causal relationship between an increase in antimicrobial resistance in human and veterinary medicine is still an important open question. The prevalence of antimicrobial resistance important for human medicine is very low in beef calves. Beef calves can be a reservoir for resistant bacteria [6]. In any case, it is very important to fight any possibility of the transfer of antimicrobial resistance between and within animals and humans by feed or food [7].

There are regional differences in the use of antibiotics even in the narrow confines of Switzerland [4]. The cantons in the French western part of Switzerland such as Geneva, Valais, Neuchatel and Vaud have a higher usage of antibiotics than the northeastern cantons like Thurgau, Sankt Gallen and Zurich [8]. Sulphonamides followed by Tetracycline and Penicillin are the most used antibiotics in Switzerland [5].

Since 1999 the use of antibiotics for growth promotion has been forbidden in Switzerland [9]. In the meantime the EU has introduced similar regulations. Additionally the use of antibiotics has to be documented [7]. As found in this present study the levels of bacterial resistance has been reduced by this antibiotic growth promotion ban, but, as mentioned by the working group, it will take a long time before a significant reduction is observed. Switzerland has a good (i.e. low) level of bacterial resistance in global terms, but there is a high risk of soil contamination by Enrofloxacin, Tetracycline, Tylosin and Sulfadiazine, as in Belgium, Ireland, the Netherland, Germany and Great Britain [10]. 
Finally, multi resistant bacteria are of major concern. Therefore antibiotics have to be used with considerable caution, and their use restricted to skilled specialist practitioners. Monitoring the use of antibiotics and the prevalence of bacterial resistance in human and veterinary medicine is of major importance, and arguably one of the key areas in global one health [11]-[13].

\section{Conclusion}

Bacteriological resistance was not measured as resistance to a certain bacteria against a given antibiotic, but rather resistance against a specific disease, i.e. calve pneumonia and diarrhoea. There are regional differences in the use of antibiotics even in the narrow confines of Switzerland. The overall situation of antimicrobial resistance within the Swiss farm animal population is stable over time. But there is an indication that antimicrobial resistance is depending on the amount of the respective antibiotic. This finding raises the obvious question whether antibiotics should be removed from the marked ones by a period of about 10 years to avoid antimicrobial resistancy. This would help to control not only bacterial resistance but also the use of the limited amount of antimicrobial drugs available. Such a control program would need to be established by international and national drug agencies as well as the pharmaceutical industry. Such a program would require extensive international validation.

\section{References}

[1] Hassig, M., Stadler, T. and Lutz, H. (2007) Transition from Maternal to Endogenous Antibodies in New Born Calves. Veterinary Record, 160, 234-235. http://dx.doi.org/10.1136/vr.160.7.234

[2] Hässig, M., Wetli, U., Lutz, H. and Suter, M. (2012) Einfluss kolostraler Antikörper auf die postvakzinale humorale Immunantwort bei neonatalen Kälbern. Schweizer Archiv für Tierheilkunde, 154, 141-147. http://dx.doi.org/10.1024/0036-7281/a000317

[3] Radostits, O.M. and Blood, D.C. (1985) Herd Health. W.B. Saunders, Philadelphia.

[4] (2012) Anonym: Die Bundesbehörden der Schweizerischen Eidgenossenschaft: Weniger Antibiotika in der Veterinärmedizin. BVET, Swissmedic. http://www.news.admin.ch/message/index.html?lang=de\&msg-id=41281.

[5] (2010) Anonym: ARCH-VET: Berichtüber den Vertrieb von Antibiotika in der Veterinärmedizin und das Antibiotikaresistenzmonitoringbei Nutztieren in der Schweiz. Bundesamtfür Veterinärwesen BVET, Swissmedic, Schweizerisches Heilmittelinstitut.

[6] Di Labio, E., Regula, G., Steiner, A., Miserez, R., Thomann, A. and Ledergerber, U. (2007) Antimicrobial Resistance in Bacteria from Swiss Veal Calves at Slaughter. Zoonoses Public Health, 54, 344-352. http://dx.doi.org/10.1111/j.1863-2378.2007.01071.x

[7] (2000) Anonym: Ko ordinations gruppe antibiotika resistente Mikroorganismen: Bakterielle Antibiotika resistenz in den Bereichen Humanmedizin, Veterinärmedizin und Lebensmittel. Universität Zürich, Bern, Lugano, ETH Zürich. Bundesamtfür Gesundheit.

[8] Filippini, M., Masiero, G. and Moschetti, K. (2006) Socioeconomic Determinants of Regional Differences in Outpatient Antibiotic Consumption: Evidence from Switzerland. Health Policy, 78, 77-92. http://dx.doi.org/10.1016/j.healthpol.2005.09.009

[9] (2001) Anonym: Bundesamtfür Veterinärwesen: Zoonosebericht 2001, Antibiotikaresistenz. BVET Magazin 2001.

[10] De La Torre, A., Iglesias, I., Carballo, M., Ramirez, P. and Munoz, M. (2011) An Approach the Vulnerability of European Union Soils to Antibiotic Contamination. Science of the Total Environment, 414, 672-679. http://dx.doi.org/10.1016/j.scitotenv.2011.10.032

[11] Berge, A.C., Atwill, E.R. and Sischo, W.M. (2005) Animal and Farm Influences on the Dynamics of Antibiotic Resistance in Faecal Escherichia coli in Young Dairy Calves. Preventive Veterinary Medicine, 69, 25-38. http://dx.doi.org/10.1016/j.prevetmed.2005.01.013

[12] Hofacre, C.L., White, D.G., Maurer, J.J., Morales, C., Lobsinger, C. and Hudson, C. (2001) Characterization of Antibiotic-Resistant Bacteria in Rendered Animal Products. Avian Diseases, 45, 953-961. http://dx.doi.org/10.2307/1592874

[13] Huber, H., Giezendanner, N., Stephan, R. and Zweifel, C. (2011) Genotypes, Antibiotic Resistance Profiles and Microarray-Based Characterization of Methicillin-Resistant Staphylococcus aureus Strains Isolated from Livestock and Veterinarians in Switzerland. Zoonoses Public Health, 58, 343-349. http://dx.doi.org/10.1111/j.1863-2378.2010.01353.x 
Scientific Research Publishing (SCIRP) is one of the largest Open Access journal publishers. It is currently publishing more than 200 open access, online, peer-reviewed journals covering a wide range of academic disciplines. SCIRP serves the worldwide academic communities and contributes to the progress and application of science with its publication.

Other selected journals from SCIRP are listed as below. Submit your manuscript to us via either submit@scirp.org or Online Submission Portal.
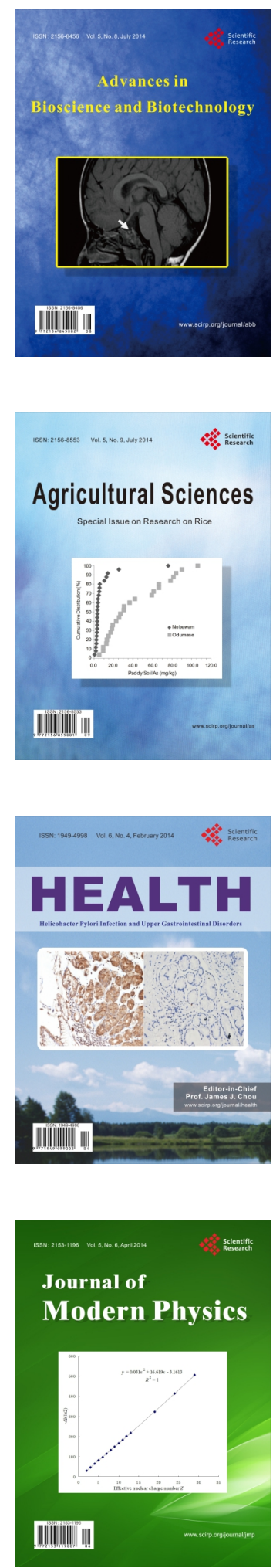
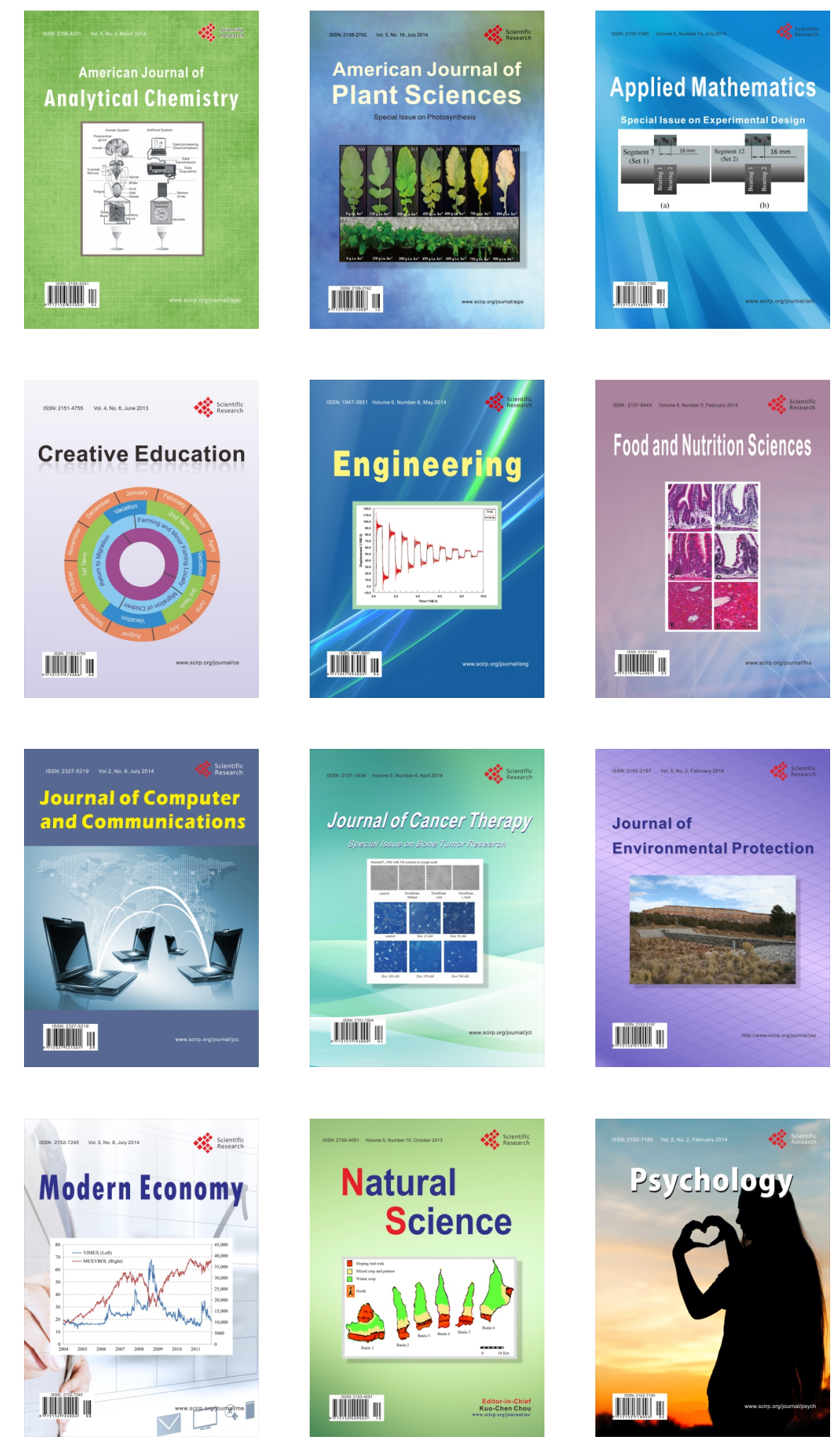